\title{
Influence of Vanadium Content on Bainitic Transformation of a Low-Carbon Boron Steel During Continuous Cooling
}

\author{
Kwang-Su Kim $\cdot$ Lin-Xiu Du $\cdot$ Cai-Ru Gao
}

Received: 30 January 2015/Revised: 12 February 2015/Published online: 4 March 2015

(C) The Chinese Society for Metals and Springer-Verlag Berlin Heidelberg 2015

\begin{abstract}
The phase transformation behaviors during continuous cooling of low-carbon boron steels with different vanadium contents were studied by means of dilatometric measurement and microstructure observation. The bainite transformation behavior is not noticeably altered when the vanadium content is 0.042 and $0.086 \mathrm{wt} \%$, and these steels exhibit full bainitic microstructure even at a cooling rate of $5{ }^{\circ} \mathrm{C} / \mathrm{s}$. When vanadium content is increased to $0.18 \mathrm{wt} \%$, ferrite is still present in the microstructure even at a cooling rate of $40{ }^{\circ} \mathrm{C} / \mathrm{s}$. Vickers hardness of the steels with 0.042 and $0.086 \mathrm{wt} \% \mathrm{~V}$ is remarkably higher than that of the steel with $0.18 \mathrm{wt} \% \mathrm{~V}$ at a cooling rate higher than $10{ }^{\circ} \mathrm{C} / \mathrm{s}$, and the difference is increased with the increase in cooling rate. Moreover, the amount of coarse vanadium precipitates formed in austenite is increased with the increase in vanadium content. The optimum content of vanadium to obtain bainitic microstructure is $0.086 \mathrm{wt} \%$ in this experimental low-carbon boron steels.
\end{abstract}

KEY WORDS: Microalloyed steel; Vanadium; Bainitic transformation; Boron; Microstructure

\section{Introduction}

Recently, low-carbon bainitic steels possessing high strength and high toughness have been developed and widely used in buildings, bridges, pipelines, ship structure and automobile components [1-3]. In particular, $\mathrm{Ti}, \mathrm{Nb}$ and $\mathrm{V}$ microalloying combined with the controlled rolling and controlled cooling not only can exclude or reduce the heat treatment process but also can ensure the strength and toughness of the steel and reduce the production cost. Therefore, there have been reports on the composition

Available online at http://link.springer.com/journal/40195

K.-S. Kim · L.-X. Du ( $ه) \cdot$ C.-R. Gao

State Key Laboratory of Rolling and Automation, Northeastern

University, Shenyang 110819, China

e-mail:dulx@ral.neu.edu.cn

K.-S. Kim

Department of Materials, Kim Chaek University of Technology, Pyongyang 999093, D.P.R. Korea design and thermo-mechanical processing of the microalloyed steels [4-8]. In the composition design of steels, the study on the low-carbon bainitic steels containing boron has been extensively conducted. Boron, as surface active element, is commonly regarded as a most effective one to realize the phase transformation strengthening in the steels. The suggested mechanism of hardening effect of boron is based upon the assumption that solute boron atoms easily segregate to the prior austenite grain boundaries before ferrite transformation $[9,10]$. The use of microalloying elements such as $\mathrm{Ti}, \mathrm{Nb}$ and $\mathrm{V}$ plays an important role in the composition design of high-strength steel as well. Particularly, vanadium is the most commonly used element $[11,12]$. The reason is that the solubility of vanadium carbide in austenite is significantly higher than those of the other microalloying carbides and nitrides; therefore, many fine particles are mainly precipitated during the phase transformation of austenite to ferrite or in the heat preservation process after transformation, such that its precipitation strengthening effect is relatively large among microalloying elements $[13,14]$. 
New low-cost bainitic steel with high strength can be obtained by taking the effect of boron on the phase transformation strengthening into account with that of vanadium on the precipitation strengthening. Many investigations have described the effects of vanadium on the phase transformation and microstructure; however, most of them have been mainly focused on the multi-microalloyed steels using $\mathrm{Mo}, \mathrm{Ni}, \mathrm{Ti}, \mathrm{Nb}$ and $\mathrm{Cu}$ [15-17]. Additionally, the research on the production of the bainitic steel plate by using $\mathrm{V}$ and $\mathrm{B}$ has not been reported in detail. For a given steel composition, the phase transformation behavior and microstructure can be significantly affected by thermomechanical controlled processing (TMCP), so that it is necessary to examine the influence of alloying elements on the dynamic continuous cooling transformation (CCT).

The present work is aimed at designing low-cost V-B microalloyed high-strength bainitic steel without adding expensive elements such as $\mathrm{Mo}, \mathrm{Cr}, \mathrm{Ni}$ and $\mathrm{Nb}$. The influences of vanadium content on bainite transformation behavior, microstructural evolution and precipitation behavior were investigated for these low-carbon boron steels with different vanadium content.

\section{Experimental}

Three steels with different compositions were designed for experiment, with $0.042,0.086$ and $0.18 \mathrm{wt} \% \mathrm{~V}$, which were denoted as No. 1, No. 2 and No. 3 steel, respectively. The chemical compositions of the experimental steels are given in Table 1 . About $0.002 \mathrm{wt} \%$ boron was added to the steels to improve the hardenability. These steels were melted in the vacuum induction furnace and cast into $50 \mathrm{~kg}$ ingots. The ingots were then homogenized at $1200{ }^{\circ} \mathrm{C}$ for $2 \mathrm{~h}$ and hot-rolled to 12 -mm-thick plates. The cylindrical specimens for dilatometer studies were cut from the hotrolled plates and machined into $\phi 8 \mathrm{~mm} \times 15 \mathrm{~mm}$ in size.

The Gleeble-1500 thermo-mechanical simulator was used to measure the transformation temperatures of the experimental steels. The specimens were reheated to $1150{ }^{\circ} \mathrm{C}$ and held for $180 \mathrm{~s}$ to dissolve vanadium and subsequently cooled to the deformation temperature of $900{ }^{\circ} \mathrm{C}$ and held for $20 \mathrm{~s}$ to eliminate the temperature gradient. The specimens were finally compressed to a strain of 0.4 at a strain rate of $5 \mathrm{~s}^{-1}$ and cooled to room temperature at different cooling rates of $0.5,1,2,5,10,20,30$ and $40{ }^{\circ} \mathrm{C} / \mathrm{s}$.

Metallographic observations were conducted by means of a Leica DMIRM optical microscope (OM) and a FEI Quanta 600 scanning electron microscope (SEM). Metallographic specimens were mechanically polished and etched with 3 vol\% nital. Transmission electron microscopy (TEM) studies were conducted on thin foils of $3 \mathrm{~mm}$ in diameter, which were electro-polished using a solution of 8 vol\% perchloric acid alcohol, and examined by an FEI Tecnai $\mathrm{G}^{2}$ F20 TEM. The composition of the precipitates was investigated by an energy-dispersive X-ray spectroscopy (EDX). The Vickers hardness of specimens with different cooling rates was tested by a Vickers hardness tester under $98 \mathrm{~N}$ load. The CCT diagrams were plotted by transformation temperatures determined on the dilatometric curves with the help of metallographic observation and lever rule.

\section{Results and Discussion}

\subsection{Transformation Behavior}

The dynamic CCT diagrams of the three experimental steels described in Table 1 are presented in Fig. 1. As shown in Fig. 1, all of the CCT diagrams revealed complex microstructures when the cooling rate is increased from 0.5 to $40{ }^{\circ} \mathrm{C} / \mathrm{s}$. These experimental steels contain boron element that prevents the formation of ferrite and pearlite even at low cooling.

For No. 1 steel, polygonal ferrite $(\mathrm{PF})$, pearlite $(\mathrm{P})$, bainite (B) and martensite (M) were involved in the dynamic CCT diagram, as shown in Fig. 1a. The starting temperature of ferrite transformation was in the range of 726-650 ${ }^{\circ} \mathrm{C}$, and polygonal ferrite was produced under cooling rates of $0.5-2{ }^{\circ} \mathrm{C} / \mathrm{s}$. Bainite was produced over a wide range of cooling rates from $0.5{ }^{\circ} \mathrm{C}$ to $40{ }^{\circ} \mathrm{C} / \mathrm{s}$. In particular, the full bainitic microstructure was obtained even at the low cooling rate of $5{ }^{\circ} \mathrm{C} / \mathrm{s}$. The mixed microstructures of bainite and martensite were observed at the cooling rate higher than $20^{\circ} \mathrm{C} / \mathrm{s}$. For No. 2 steel, the starting temperature of ferrite transformation was in the

Table 1 Chemical compositions of the experimental steels (wt\%)

\begin{tabular}{llllllllllll}
\hline Steel & $\mathrm{C}$ & $\mathrm{Si}$ & $\mathrm{Mn}$ & $\mathrm{P}$ & $\mathrm{S}$ & $\mathrm{Al}$ & $\mathrm{V}$ & $\mathrm{Ti}$ & $\mathrm{N}$ & $\mathrm{B}$ & $\mathrm{Fe}$ \\
\hline No. 1 & 0.12 & 0.17 & 1.76 & 0.003 & 0.002 & 0.026 & 0.042 & 0.005 & 0.004 & 0.0021 & Bal. \\
No. 2 & 0.12 & 0.14 & 1.76 & 0.002 & 0.002 & 0.027 & 0.086 & 0.005 & 0.004 & 0.0019 & Bal. \\
No. 3 & 0.11 & 0.13 & 1.77 & 0.003 & 0.002 & 0.025 & 0.18 & 0.005 & 0.004 & 0.0020 & Bal. \\
\hline
\end{tabular}

$\mathrm{Ti}$ and $\mathrm{N}$ were not added purposefully 

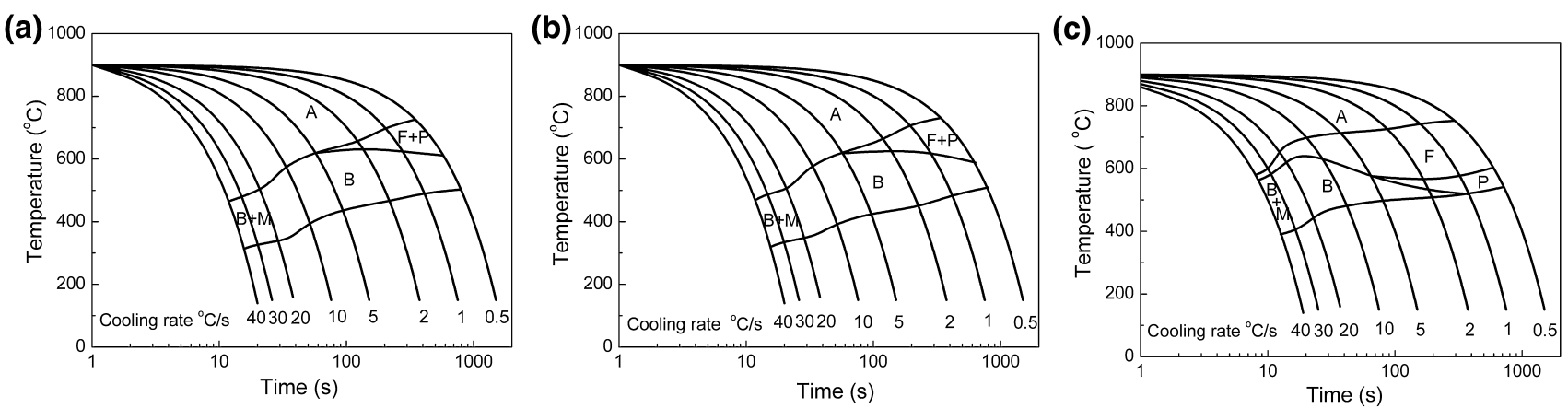

Fig. 1 Dynamic CCT diagrams of the steels with different V contents: a No. 1 steel, 0.042 wt\% V; b No. 2 steel, 0.086 wt $\%$ V; c No. 3 steel, $0.18 \mathrm{wt} \% \mathrm{~V}$

range of $731-657^{\circ} \mathrm{C}$, as shown in Fig. 1b. Comparing the dynamic CCT diagram of No. 2 steel (Fig. 1b) with that of No. 1 steel (Fig. 1a), only a slight difference could be observed, which means that their transformation behaviors were similar. As for No. 3 steel, dynamic CCT diagram (Fig. 1c) had much difference with those of No. 1 and No. 2 steels, which was caused by the vanadium increase. Pearlite was observed at cooling rates from 0.5 to $2{ }^{\circ} \mathrm{C} / \mathrm{s}$, and bainite was formed at a cooling rate higher than $2{ }^{\circ} \mathrm{C} / \mathrm{s}$. The starting temperature range of ferrite transformation was $753-723^{\circ} \mathrm{C}$ under cooling rates of $0.5-2{ }^{\circ} \mathrm{C} / \mathrm{s}$. It should be noted that the ferrite transformation of No. 3 steel proceeded over a wide range of cooling rates from 0.5 to $40{ }^{\circ} \mathrm{C} / \mathrm{s}$.

It can be concluded from the above results that the ferrite transformation field is obviously expanded, whereas the bainite transformation field is reduced by adding excessive amounts of vanadium to $0.18 \mathrm{wt} \%$. That is to say, vanadium when added more than the critical content has negative effect on the bainite formation. Therefore, it can be concluded that a critical content of vanadium for suppressing ferrite transformation and for obtaining full bainitic microstructure is about $0.086 \mathrm{wt} \%$ in the continuously cooled boron steel.

\subsection{Microstructures}

Figure 2 shows the typical optical micrographs of the experimental steels under different cooling rates. The volume fractions of ferrite in the experimental steels under different cooling rates are shown in Fig. 3.

It is clear from Fig. 2 to see the influence of vanadium content and cooling rate on the microstructural evolution. For No. 1 and No. 2 steels, the microstructures consisted of polygonal ferrite, pearlite and granular bainite were observed at the cooling rate of $1{ }^{\circ} \mathrm{C} / \mathrm{s}$, and the fractions of ferrite were 54 and $58 \mathrm{vol} \%$, respectively, as shown in Fig. 2a, e. For No. 3 steel, however, the granular bainite was not observed and the microstructure consisted of polygonal ferrite $(\sim 78 \mathrm{vol} \%)$ and pearlite (Fig. $2 \mathrm{i})$. That is, increasing the vanadium content leads to obvious increase in ferrite amount. The volume fractions of ferrite in No. 1 and No. 2 steels were rapidly decreased with increasing cooling rate as compared to No. 3 steel (Fig. 3). When the cooling rate was $5{ }^{\circ} \mathrm{C} / \mathrm{s}$, the transformation of ferrite and pearlite was suppressed and the microstructures mainly consisted of granular bainite in No. 1 and No. 2 steels, as shown in Fig. 2c, g. As for No. 3 steel, however, a large amount of ferrite $(\sim 63 \mathrm{vol} \%)$ was still present in the microstructure (Fig. 2k).

Figure 4 shows the SEM micrographs of the experimental steels with cooling rate of $10{ }^{\circ} \mathrm{C} / \mathrm{s}$. For No. 1 and No. 2 steels, the lath bainite is shown in Fig. 4a, b, respectively, and its fraction was increased with increasing cooling rate, whereas polygonal ferrite was still exhibited in No. 3 steel, and most of them was formed along prior austenite grain boundaries (Fig. 4c).

As mentioned above, the microstructures of No. 2 steel are similar to those of No. 1 steel under the CCT, and only a slight difference in phase fraction can be observed. This fact is given in the transformation kinetics, where the two experimental steels have almost the same CCT diagram. When the vanadium content is increased to $0.18 \mathrm{wt} \%$, ferrite is still present in the microstructures over the wide range of cooling rates, and $12 \mathrm{vol} \%$ ferrite can be found even at $40{ }^{\circ} \mathrm{C} / \mathrm{s}$.

To obtain bainite in the experimental steels, the ferrite transformation must be delayed as far as possible. Medina et al. [18] described the nucleation sites of ferrite in austenite. The austenite grain boundaries, dislocation, other crystal defects and carbonitride of the microalloying elements could be preferential nucleation sites of ferrite. Vanadium in experimental steels can affect the transformation and microstructure in two forms, i.e., precipitates and solid solution. In general, the vanadium precipitates are mainly formed in the phase transformation process or the heat preservation process after transformation [19]. As it was reported in Ref. [20], however, particularly when the 

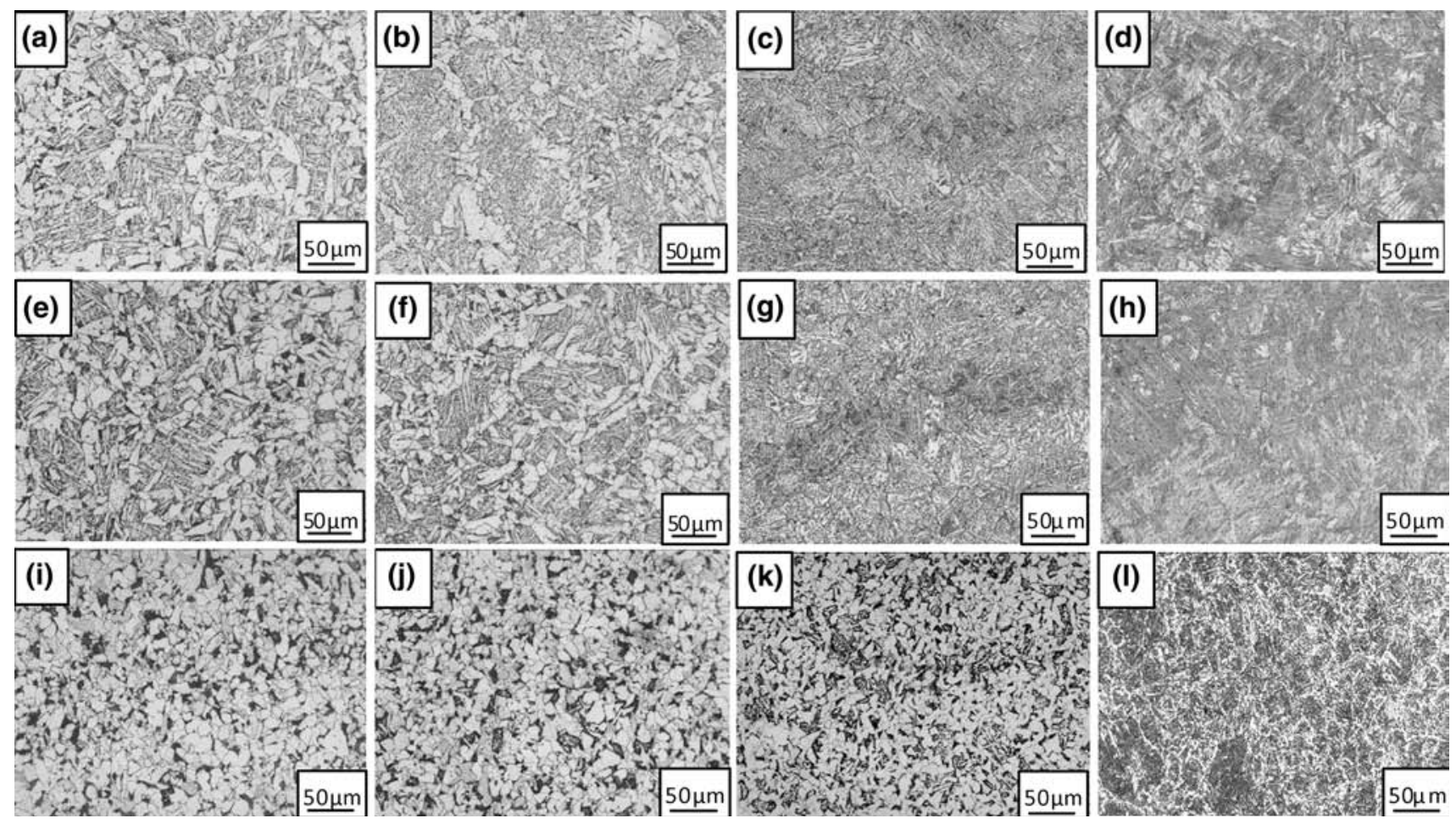

Fig. 2 Optical micrographs of experimental steels with different $\mathrm{V}$ contents after continuous cooling to room temperature under different cooling rates: a $0.042 \mathrm{wt} \% \mathrm{~V}, 1{ }^{\circ} \mathrm{C} / \mathrm{s} ; \mathbf{b} 0.042 \mathrm{wt} \% \mathrm{~V}, 2{ }^{\circ} \mathrm{C} / \mathrm{s} ; \mathbf{c} 0.042 \mathrm{wt} \% \mathrm{~V}, 5^{\circ} \mathrm{C} / \mathrm{s} ; \mathbf{d} 0.042 \mathrm{wt} \% \mathrm{~V}, 40{ }^{\circ} \mathrm{C} / \mathrm{s} ; \mathbf{e ~} 0.086 \mathrm{wt} \% \mathrm{~V}, 1{ }^{\circ} \mathrm{C} / \mathrm{s}$; f $0.086 \mathrm{wt} \% \mathrm{~V}, 2{ }^{\circ} \mathrm{C} / \mathrm{s} ; \mathbf{g} 0.086 \mathrm{wt} \% \mathrm{~V}, 5{ }^{\circ} \mathrm{C} / \mathrm{s} ; \mathbf{h} 0.086 \mathrm{wt} \% \mathrm{~V}, 40{ }^{\circ} \mathrm{C} / \mathrm{s} ; \mathbf{i} 0.18 \mathrm{wt} \% \mathrm{~V}, 1{ }^{\circ} \mathrm{C} / \mathrm{s} ; \mathbf{j} 0.18 \mathrm{wt} \% \mathrm{~V}, 2{ }^{\circ} \mathrm{C} / \mathrm{s} ; \mathbf{k ~} 0.18 \mathrm{wt} \% \mathrm{~V}, 5{ }^{\circ} \mathrm{C} / \mathrm{s} ;$ l $0.18 \mathrm{wt} \% \mathrm{~V}, 40^{\circ} \mathrm{C} / \mathrm{s}$

carbon or nitrogen levels were high, the vanadium precipitates could be formed in austenite after solution treatment or during hot deformation as the temperature was decreasing. Hu et al. $[21,22]$ reported that the vanadium carbonitrides in austenite could act as nucleation sites for the ferrite along prior austenite grain boundaries or

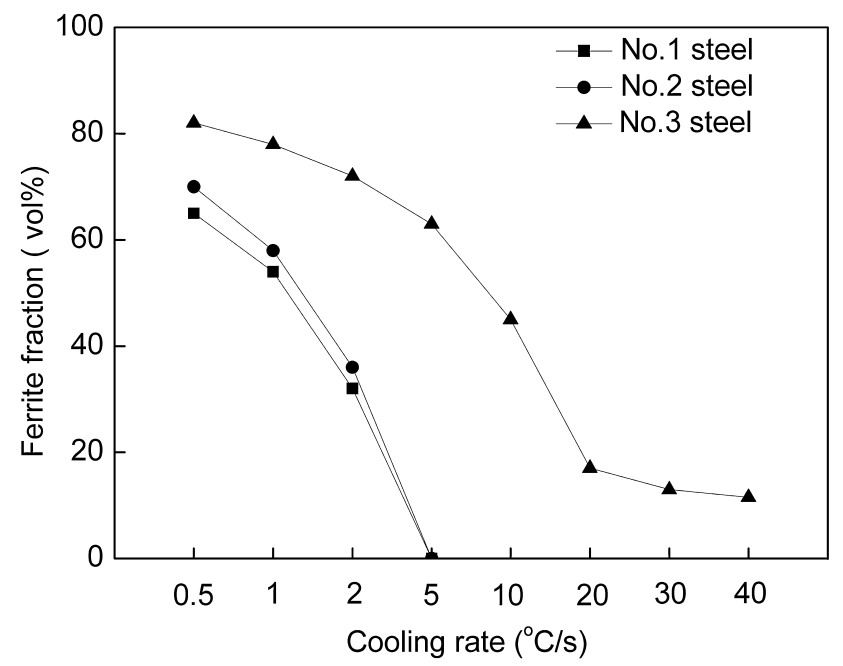

Fig. 3 Volume fraction of ferrite in the experimental steels with different $\mathrm{V}$ contents intragranular ferrite. According to Jung et al. [23], the coarse precipitates formed in austenite could accelerate ferrite nucleation.

In order to observe the formation of precipitates in experimental steels, TEM analysis was conducted on the samples continuously cooled in $10{ }^{\circ} \mathrm{C} / \mathrm{s}$. The TEM morphologies and EDX analysis result of precipitates in No. 3 steel are shown in Fig. 5. The precipitates formed in the polygonal ferrite were observed. As shown in Fig. 5b, the precipitates exhibit two sizes, i.e., $20-30$ and $3-5 \mathrm{~nm}$. The precipitates were $(\mathrm{V}, \mathrm{Ti})(\mathrm{C}, \mathrm{N})$ which are rich in vanadium and carbon as analyzed by EDX in Fig. 5c. In spite of a very low content of nitrogen and titanium (those were not added purposefully) in experimental steel, the carbonitrides of vanadium and titanium were observed due to titanium's strong affinity for carbon and nitrogen and relatively high content of vanadium.

Combining TEM analysis with optical microscopy results, it is considered that the $20-30 \mathrm{~nm}$ precipitates were nucleated during heat preservation and hot deformation processes, and the 3-5 $\mathrm{nm}$ precipitates were formed during continuous cooling stage. Figure 6 shows TEM micrograph and precipitate morphologies of No. 2 steel sample. Compared with the No. 3 steel, a very small amount of the precipitates were observed due to relatively low content of 

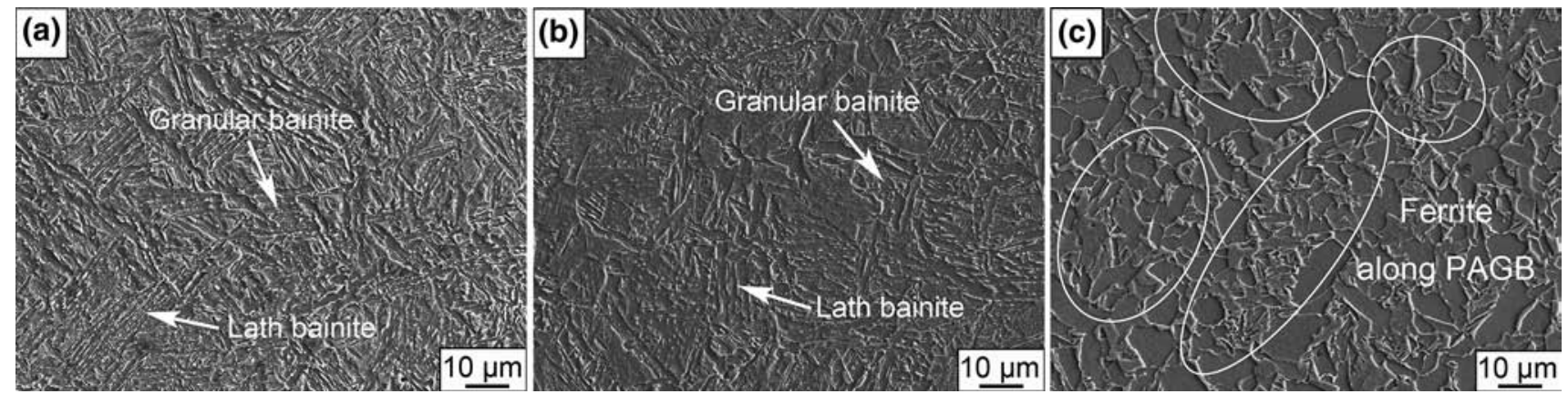

Fig. 4 SEM micrographs of experimental steels after continuous cooling to room temperature under cooling rates of $10{ }^{\circ} \mathrm{C} / \mathrm{s}$ : a No. 1 steel composed of granular bainite and lath bainite; b No. 2 steel composed of granular bainite and lath bainite; c No. 3 steel composed of granular bainite and polygonal ferrite

vanadium. Furthermore, in the No. 1 sample, the precipitates were not almost observed.

The results show that in the case of high content of vanadium, although the content of nitrogen is low, the coarse vanadium precipitates could be formed in austenitic region at $900{ }^{\circ} \mathrm{C}$, and hence, ferrite transformation could be promoted because of additional nucleation site of the precipitates. The higher the vanadium content is, the larger the amount of precipitates in austenitic region there will be, as shown in Figs. 5 and 6. Therefore, ferrite transformation would be more promoted. In addition, vanadium affects the phase transformation as a solid solution state. When the content of solute vanadium is less, the effects of vanadium on the hardenability and phase transformation are much less than those of the carbon and boron. Therefore, the transformation behavior of No. 2 steel is very similar to that of No. 1 steel. However, the precipitation strengthening effect of No. 2 steel during the controlled rolling and controlled cooling would be higher than that of No. 1 steel. On the other hand, for No. 3 steel, the formation of the coarse vanadium precipitates leads to the loss of precipitation strengthening effect and waste of vanadium.

\subsection{Hardness}

The effects of vanadium content and cooling rates on Vickers hardness are shown in Fig. 7, where there was a strong dependence of $\mathrm{HV}$ values on vanadium and cooling rate. When cooling rate was lower than $5{ }^{\circ} \mathrm{C} / \mathrm{s}$, the hardness values of No. 3 steel were higher than those of the other two steels, but the difference between them was not so large. This is considered to be resulted from the fact that the solid solution strengthening is increased with the increase in vanadium content, and furthermore, as Gündüz and Cochrane [24] reported, the vanadium precipitates can be precipitated at low cooling rate.

As the cooling rate was higher than $10{ }^{\circ} \mathrm{C} / \mathrm{s}$, the hardness values of No. 1 and No. 2 steel were obviously higher than those of No. 3 steel, and the hardness of the three steel was rapidly increased with the increase in cooling rate. Mean- (a)

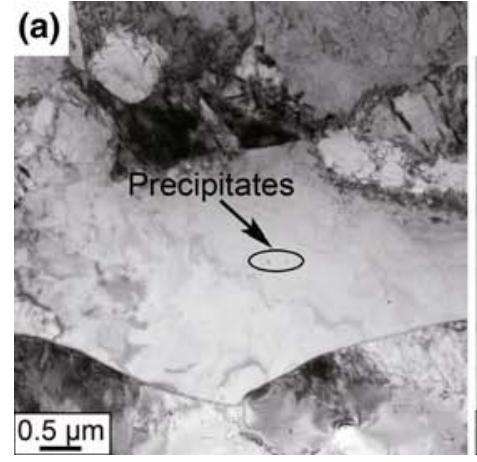

(b)

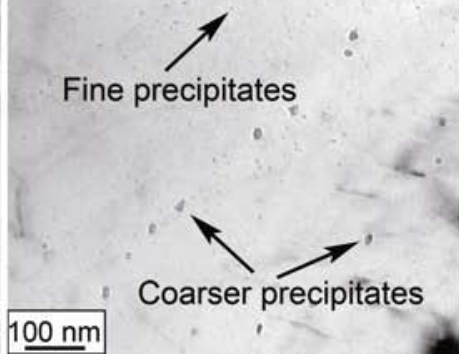

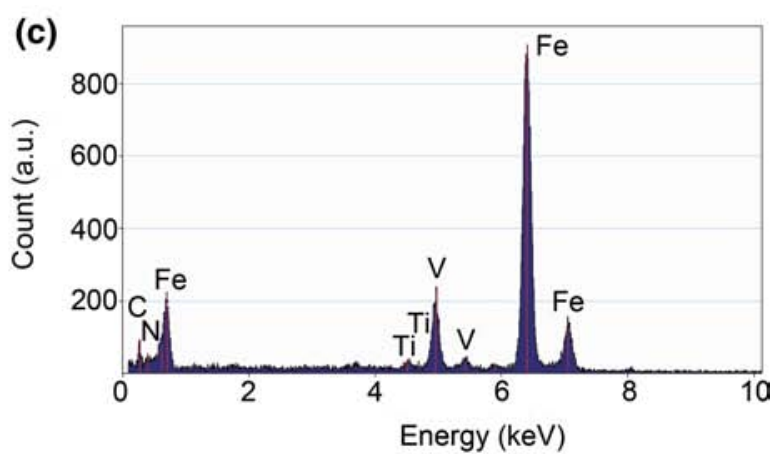

Fig. 5 TEM micrographs and EDX analysis result of precipitates in No. 3 steel cooling at $10^{\circ} \mathrm{C} / \mathrm{s}$ : a morphology of polygonal ferrite; b morphologies of fine precipitates and coarse precipitates in polygonal ferrite; c EDX analysis result of coarser precipitate 

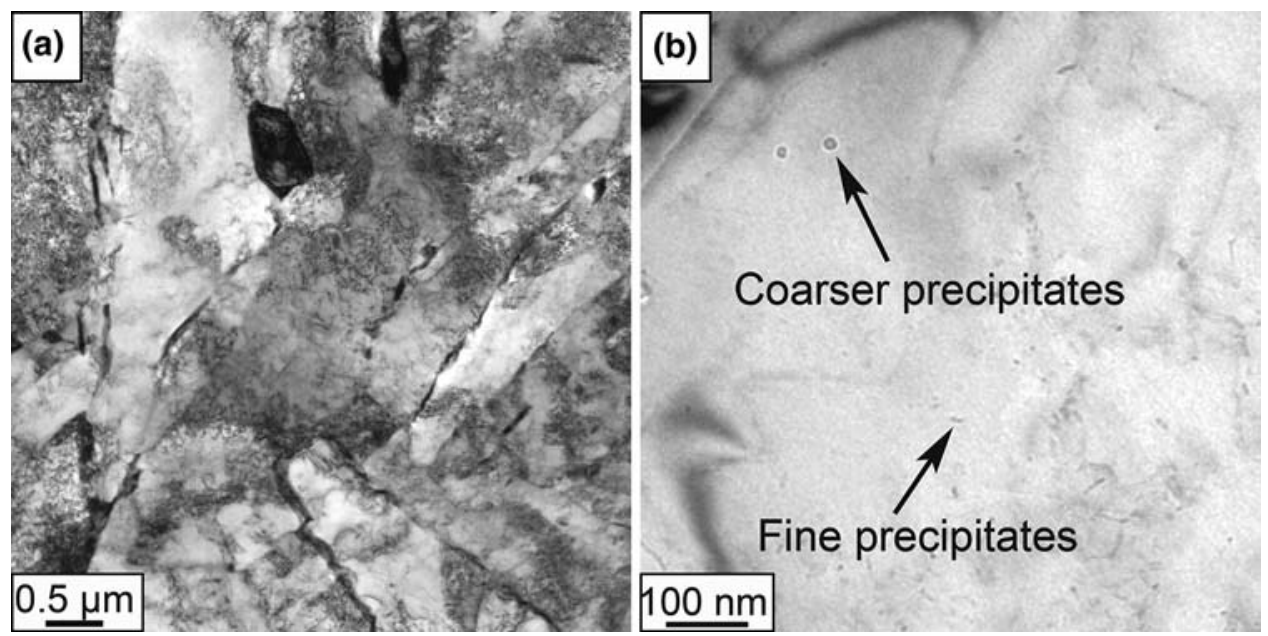

Fig. 6 TEM micrograph and precipitates morphologies of No. 2 steel cooling at $10^{\circ} \mathrm{C} / \mathrm{s}$ : a morphology of bainite; $\mathbf{b}$ morphologies of fine precipitates and coarse precipitates

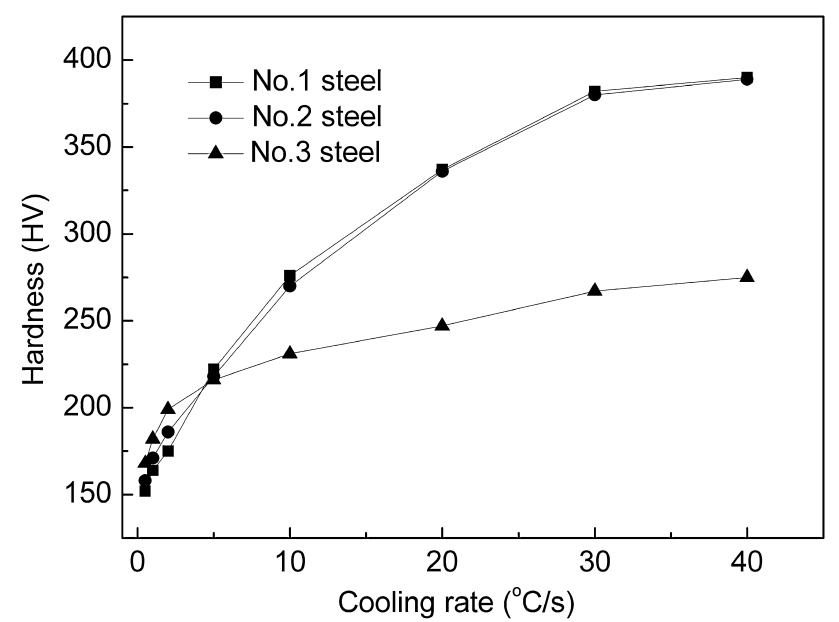

Fig. 7 Effects of cooling rate and vanadium content on Vickers hardness

while, there was almost no difference in hardness value for No. 1 and No. 2 steels at high cooling rates. The difference in hardness value for No. 3 steel and other two steels was more substantial with the increase in cooling rate, which was about $115 \mathrm{HV}$ at the cooling rate of $30-40{ }^{\circ} \mathrm{C} / \mathrm{s}$. This difference in hardness at high cooling rates seems to be related to the phase transformation strengthening. That is, the microstructures of No. 1 and No. 2 steels were composed of bainite and martensite. However, for No. 3 steel, ferrite is still present in the microstructures. These facts show that the addition of excessive amounts of vanadium into the boron steel decreases the effect of boron on the phase transformation strengthening.

The study shows that the optimum content of vanadium for the development of high-strength bainitic steel is $0.086 \mathrm{wt} \%$ in V-B microalloyed experimental steels.

\section{Conclusions}

1. The microstructures formed in continuously cooled steels consist of ferrite, pearlite, bainite and martensite, depending on vanadium content and cooling rate. The starting temperatures of ferrite transformation under cooling rates of $0.5-2{ }^{\circ} \mathrm{C} / \mathrm{s}$ are in the ranges of 726-650, $731-657$ and $753-723{ }^{\circ} \mathrm{C}$ for the steels containing 0.042 , 0.086 and $0.18 \mathrm{wt} \% \mathrm{~V}$, respectively, which indicates obvious raise by the vanadium addition up to $0.18 \mathrm{wt} \%$.

2. The bainite transformation behavior is not noticeably altered by adding vanadium of 0.042 and $0.086 \mathrm{wt} \%$. These steels exhibit full bainitic microstructures even at a low cooling rate of $5{ }^{\circ} \mathrm{C} / \mathrm{s}$. However, when the vanadium content is increased to $0.18 \mathrm{wt} \%$, the polygonal ferrite is still present in the microstructure even at a high cooling rate of $40{ }^{\circ} \mathrm{C} / \mathrm{s}$.

3. The Vickers hardness is increased with the increase in vanadium content under a cooling rate lower than $5{ }^{\circ} \mathrm{C} / \mathrm{s}$, but there is no significant difference between them. When the cooling rate is higher than $10^{\circ} \mathrm{C} / \mathrm{s}$, conversely, the hardness of the steels with 0.042 and $0.086 \mathrm{wt} \% \mathrm{~V}$ is remarkably higher than that of the steel with $0.18 \mathrm{wt} \% \mathrm{~V}$, and the difference between them is increased with the increase in cooling rate, which is about $115 \mathrm{HV}$ at the cooling rate of $30-40{ }^{\circ} \mathrm{C} / \mathrm{s}$.

4. The amount of coarse vanadium precipitates formed in austenite before continuous cooling is increased with the increase in vanadium content. The ferrite transformation is obviously promoted due to the additional nucleation site of the precipitates, especially in the steel with $0.18 \mathrm{wt} \% \mathrm{~V}$. The optimum content of vanadium to obtain bainitic microstructure is $0.086 \mathrm{wt} \%$ in V-B microalloyed steel. 
Acknowledgments This work was financially supported by the National Key Technology Research and Development Program of the Ministry of Science and Technology of China (No. 2011BAE13B03) and the Natural Science Foundation of Liaoning Province of China (No. 201202062)

\section{References}

[1] L.Y. Lan, C.L. Qiu, P. Zhou, D.W. Zhao, C.M. Li, Acta Metall. Sin. (Engl. Lett.) 24, 473 (2011)

[2] H.F. Lan, L.X. Du, R.D.K. Misra, Mater. Sci. Eng. A 611, 194 (2014)

[3] J.R. Yang, C.Y. Huang, S.C. Wang, Mater. Des. 13, 335 (1992)

[4] C. Feng, H.S. Fang, Y.K. Zheng, B.Z. Bai, J. Iron Steel Res. Int. 17(4), 53 (2010)

[5] X.W. Kong, L.Y. Lan, Z.Y. Hu, B. Li, T.Z. Sui, J. Mater. Process. Technol. 217, 202 (2015)

[6] S.H. Mousavi Anijdana, A. Rezaeian, S. Yue, Mater. Charact. 63, 27 (2012)

[7] J. Calvo, I.H. Jung, A.M. Elwazri, D. Bai, S. Yue, Mater. Sci. Eng. A 520, 90 (2009)

[8] H. Wu, C. Liu, Z. Zhao, Y. Zhao, S.Z. Zhu, Y.X. Liu, S. Bhole, Mater. Des. 27, 651 (2006)

[9] S. Yoshida, K. Ushioda, J. Ågren, ISIJ Int. 54, 685 (2014)
[10] H. Yang, X.X. Wang, J.B. Qu, J. Iron Steel Res. Int. 21, 787 (2014)

[11] T.N. Baker, Mater. Sci. Technol. 25, 1083 (2009)

[12] Y.T. Chen, A.M. Guo, L.X. Wu, J. Zeng, P.H. Li, Acta Metall. Sin. (Engl. Lett.) 19, 57 (2006)

[13] F.J. Revidriego, R. Abad, B. López, I. Gutiérrez, J.J. Urcola, Scr. Mater. 34, 1589 (1996)

[14] T. Siwecki, J. Eliasson, R. Lagneborg, B. Hutchinson, ISIJ Int. 50, 760 (2010)

[15] X. Chun, Q. Sun, X. Chen, Mater. Des. 28, 2523 (2007)

[16] B.K. Show, R. Veerababu, R. Balamuralikrishnan, Mater. Sci. Eng. A 527, 1595 (2010)

[17] C.L. Zhang, D.Y. Cai, Y.H. Wang, M.Q. Liu, B. Liao, Y.C. Fan, Mater. Charact. 59, 1638 (2008)

[18] S.F. Medina, M. Gómez, L. Rancel, Scr. Mater. 58, 1110 (2008)

[19] R. Lagneborg, T. Siwecki, S. Zajac, B. Hutchinson, Scan. J. Metall. 28, 186 (1999)

[20] T.N. Baker, Mater. Sci. Technol. 25, 1083 (2009)

[21] J. Hu, L.X. Du, J.J. Wang, H. Xie, C.R. Gao, Mater. Sci. Eng. A 590, 323 (2014)

[22] J. Hu, L.X. Du, J.J. Wang, H. Xie, Mater. Sci. Eng. A 585, 197 (2013)

[23] Y.C. Jung, H. Ueno, H. Ohtsubo, K. Nakai, Y. Ohmori, ISIJ Int. 35, 1001 (1995)

[24] S. Gündüz, R.C. Cochrane, Mater. Des. 26, 486 (2005) 